\title{
THE PAULINE CONCEPT OF ORIGINAL SIN, IN LIGHT OF RABBINIC BACKGROUND ${ }^{1}$
}

\author{
Stanley E. Porter
}

\section{Original Sin in the Rabbinic Material}

The received tradition in rabbinic studies, both of the more conservative and of the more progressive sort, is that rabbinic thought does not have a concept of original $\sin ^{2}$ Surely this is one of few large topics on which G. F. Moore, W. D. Davies, E. E. Urbach and E. P. Sanders fully agree. It is particularly interesting that such unanimity of opinion can be found, but it is also noteworthy that not one of these major scholars takes time to define what exactly original sin is. Even so extensive a recent work as E. P. Sanders's Paul and Palestinian Judaism says categorically: 'It is not necessary to discuss here Rabbinic speculation on the origin of sinful disobedience. This sort of theological speculation, like speculation concerning the nature of the world to come, lies outside the scope of the Rabbinic pattern of religion' ${ }^{3}$ Sanders continues:

Yet it is important to note that the Rabbis did not have a doctrine of original sin or of the essential sinfulness of each man in the Christian

\footnotetext{
${ }^{1}$ This paper is a major revision of a paper first read to the Tyndale Fellowship Joint Biblical and Historical/Systematic Theology Study Group, 3 July 1986.

${ }^{2}$ Standard works on this topic include: H. St. J. Thackeray, The Relation of St. Paul to Contemporary Jewish Thought (London: Macmillan, 1900) 29-57; F. R. Tennant, The Sources of the Doctrines of the Fall and Original Sin (C.U.P. 1903) esp. 145-76; S. Schechter, Some Aspects of Rabbinic Theology (London, Adam and Charles Black, 1909) 242-63; N. P. Williams, The Ideas of the Fall and of Original Sin: A Historical and Critical Study (London, Longmans, Green 1927) 39-163; G. F. Moore, Judaism in the First Centuries of the Christian Era: The Age of the Tannaim, 3 vols. (Cambridge, Harvard Univ. Press 1927-30) 1.47993; C. G. Montefiore and H. Loewe, A Rabbinic Anthology (London, Macmillan 1938) 295-314 (cited as $R A$ ); R. A. Stewart, Rabbinic Theology: An Introductory Study (Edinburgh, Oliver and Boyd 1961) 76-92; E. E. Urbach, The Sages: Their Concepts and Beliefs (ET Jerusalem, Magnes, 19792) 420-36, 874-9; and W. D. Davies, Paul and Rabbinic Judaism: Some Rabbinic Elements in Pauline Theology (Philadelphia, Fortress 19804) 17-35.

${ }^{3}$ E. P. Sanders, Paul and Palestinian Judaism: A Comparison of Patterns of Religion (London, SCM 1977) 114.
} 
sense. It is a matter of observation that all men sin. Men have, apparently, the inborn drive towards rebellion and disobedience. But this is not the same as being born in a state of sinfulness from which liberation is necessary. Sin comes only when man actually disobeys; if he were not to disobey he would not be a sinner. ${ }^{4}$

Surely Sanders is right that the rabbis did not have a definition of original sin in the Christian sense. But, more importantly, what is of concern is whether the rabbis had any sustained or developed reflection on where sin came from, regardless of whether one is willing to call it original sin or not. Indeed, it appears that they did.

The discussion referred to is that of the bad and good natures or impulses (focusing upon use of yetzer hara and yetzer hatov). ${ }^{5}$ The evidence for this concept is developed to its largest extent in Talmudic and Midrashic writings, and thus is rightly seen to be late, although several scholars argue that occasional reference in earlier Jewish literature either shows its origins or reveals its earlier existence as part of a general discussion in the Jewish world. 6 The most likely source of course would be the OT. Genesis 6:5 says 'the Lord saw that the wickedness of man was great in the earth and that the entire impulse (יצ') of the thoughts of his heart was only evil (ר) continually'. N. P. Williams has argued that two traditions in the OT regarding evil were later developed in Jewish thought-the first in Genesis 2-3 and the other in Genesis $6 .^{7}$ But since reference to Genesis 6 does not figure significantly in rabbinic interpretation this would argue against its being the source of the theory of the two natures. Another reference must also be considered. Genesis 8:21: "The Lord said in his heart, I

\footnotetext{
${ }^{4}$ Sanders, Paul 114. Sanders refers in a footnote to G. F. Moore and others on 'the origin of $\sin ^{\prime}$ (n. 49).

${ }^{5}$ See esp. those cited in $\mathrm{n} .2$ above, as well as A. P. Hayman, 'Rabbinic Judaism and the Problem of Evil', SJT 29 (1976) 461-76.

${ }^{6} \mathrm{On}$ the questions of dating and use of rabbinic material see: J. Neusner, "Judaism" after Moore, A Programmatic Statement', JJS 31 (1980) 141-56; idem, New Problems, New Solutions: Current Events in Rabbinic Studies', Method and Meaning in Ancient Judaism, Third Series (Chico, California: Scholars Press 1981) 61-81; P. S. Alexander, 'Rabbinic Judaism and the NT', ZNW 74 (1983) 237-46; and B. Chilton, A Galilean Rabbi and His Bible: Jesus' Own Interpretation of Isaiah (London, SPCK 1984) esp. 13-35.

7Williams, Ideas $20 \mathrm{ff}$.
} 
will not again curse the ground any more for man's sake; for the impulse ( $7{ }^{\prime}$ ) of man's heart is evil (ר) from his youth'. Here God is addressing something which is seen as constituting part of human nature, though it also constitutes a justification for God to destroy humanity. These references, as well as other OT passages using yetzer, provide little help in establishing the textual origins of the rabbinic concept of evil, since the rabbinic material does not seem at this point to extend OT thought directly. If later writers used the OT in any significant way, it appears that they found the language suggestive rather than compelling.

Another possible source of reference to the good and bad natures is the Qumran literature, especially the Thanksgiving Psalms, although they seem rather to refer to human weakness than any inclination or nature of humankind. A few passages may have a meaning closer to the idea of nature or disposition, but even then the lines are tenuous. For example, $1 \mathrm{QH} 11.19-20$, says, 'trouble was not hidden from mine eyes, for I came to know the inclinations of man and mankind's return [to dust ... .] to sin and sorrow over guilt'.8 As Ringgren points out,

If there were not the rabbinic teaching concerning the good and evil yeser the idea of impulses or inclinations in man would probably not suggest itself immediately. It is probably not a question of original sin but of a certain 'predisposition' to sin, which clearly follows from man's total dissimilarity to God. ${ }^{9}$

Thus it is not entirely clear how the concept of the good and bad natures arose in rabbinic writing, except that later formulators were apparently indirectly dependent upon a variety of thought adumbrated early on by the OT and partially developed in other Jewish circles. This perhaps accounts for the relative diversity in rabbinic thought, although it does not account for the apparent lateness of its appearance. In one of the few early examples, found in the Mishnah, not usually concerned with this kind of material, Ben

${ }^{8}$ H. Ringgren, The Faith of Qumran: Theology of the Dead Sea Scrolls (ET Philadelphia, Fortress 1963) 103.

${ }^{9}$ Ringgren, Faith 102. Cf. R. E. Murphy, 'Yeser in the Qumran Literature', Bib 39 (1958) $334-4$. 
Zoma (AD 120-40), a Tannaitic teacher, says, Who is mighty? He that subdues his [evil] nature' (Aboth 4.1 [Danby]).

In later writings a more developed-though not entirely unproblematic-concept can be found, although it is clearly not schematized. In several texts God is said to have made and placed the inclinations within the individual: 'Our Rabbis taught: The Evil Desire is hard [to bear], since even his Creator called him evil' (b Kiddushin 30b [Soncino]); or in a third century AD account: 'So God said: "It was I who put the bad leaven in the dough, for the yetzer of the heart of man is evil from his youth"' (Tanh. B., Noah, 15b [RA 300]).

One indication of the possible relative earliness of the tradition regarding God placing the evil nature within the individual is the further reflection that it generated. For example, on Genesis 6:6, ' R. Aibu [4th century] interpreted: It was a regrettable error on My part to have created an evil urge (yezer ha-ra') within him, for had I not created an evil urge within him, he would not have rebelled against $\mathrm{Me}^{\prime}$ (Gen. Rabba, Bereshith, 27.4 [Soncino]), or 'God regretted the evil inclination, and He said, "What damage have I wrought!" (Tanh.d.b.El. p. 62 [RA 301]). Logically, if God created the evil inclination it would seem that to exercise it would be appropriate, but such is not the case. 'If the evil inclination say to thee: Sin and the Holy One, blessed be $\mathrm{He}$, will pardon, believe it not' (b. Hagigah 16a [Soncino]).

This obvious tension between God creating the evil inclination and later regretting its presence in humanity generated several different resolutions, although it must be remembered that no systematic attempt was made to smooth over all difficulties. Some tradition gets fairly complex:

But if you say, 'Why did God create the yetzer?' or, No man can keep himself (from the power of the yetzer)', the reply is: 'Why does a child of five, six, seven, eight or nine years not sin, but only at ten years and upwards? He himself makes his yetzer big. You make your yetzer bad'. (Tanh., Bereshith, par. 7, f. 10a [RA 301-02])

It appears that earlier tradition in the rabbinic writing may have attributed the evil impulse directly to God, but this ascription later was thought to be out of character with God's 
nature, ${ }^{10}$ and secondary causes more directly related to the human were developed. As an example, R. Simeon b. Levi (c. AD 280) said, 'Man's Evil Desire gathers strength against him daily and seeks to slay him ... and were not the Holy One, blessed be He, to help him [man], he would not be able to prevail against him' (b Kiddushin 30b [Soncino]).

It is almost inevitable that the law should be introduced somewhere, but even here reflection is mixed: Raba (c. AD 350) said, 'If God created the evil inclination, he also created the Torah as its antidote' (b Baba Bathra 16a [Soncino]). But compare the following:

The evil inclination desires only that which is forbidden. R. Mena [4th century] went to visit R. Haggai who was ill. R. Haggai said, I am thirsty'. R. Mena said, 'Drink'. Then he left him. After an hour he came again, and said, 'How about your thirst?' He said, No sooner had you permitted me to drink than the desire left me'. (p Yoma 6, par. 4, 43d, line 21 [RA 302])

From what has been said, it would appear that no matter its origin, or even no matter its remedy, the evil yetzer is a bad thing. But even this is not a universal principle:

Nahman [3rd century] said in R. Samuel's name: BEHOLD, IT WAS VERY GOOD refers to the Good Desire; AND BEHOLD, IT WAS VERY GOOD, to the Evil Desire. Can then the Evil Desire be very good? That would be extraordinary! But for the Evil Desire, however, no man would build a house, take a wife and beget children. (Gen. Rabba, Bereshith, 9.7 [Soncino])

Throughout the tradition, there are several passages where sex is closely linked with the evil inclination, although several are more suggestive than explicit, locating the inclination variously on one's right side for the good and the left for the bad (Num. Rabba 22.9), in the kidneys (b. Bereshith 61a), or especially in the heart (Sifre Deut. 6.5 par. 32). What then did the rabbis do with the story of Adam and Eve? Generally such reflection appears to be late. There is a hint of blaming woman in several instances, including a passage: which says that 'When the serpent copulated with Eve, he infused her with lust' (b Yebamoth 103b [Soncino]); where it is intimated

${ }^{10}$ See Hayman, 'Rabbinic Judaism and Evil' 464 ff. 
that the serpent deceived Eve' (Gen. Rabba, Bereshith, 18-19); and, even more strongly, where $R$. Joshua says, 'Because they [women] brought death into the world, they therefore walk in front of the corpse [at a funeral]' (Gen. Rabba, Bereshith, 17.8 [Soncino]). It is not possible to discuss here the many myths which grew up around Adam or the imagery which surrounds him in Jewish writing, but it appears that whereas in rabbinic writing sin is a matter of individual choice in response to the urging of the evil impulse, only death can be attributed to Adam and Eve. Urbach claims in fact that R. Akiba (d. AD 132) and his disciples nowhere attribute 'the existence of sin to Adam's transgression', nor 'the actual existence of death to human sins', ${ }^{11}$ but each dies on account of his own transgression. Gen. Rabba, Bereshith, 9.5 states, however, that R. Hama b. R. Hanina (c. AD 280) said: 'Adam deserved to be spared the experience of death. Why then was the penalty of death decreed against him? Because the Holy One ... foresaw that Nebuchadnezzar and Hiram would declare themselves gods; therefore was death decreed against him' (Soncino).

To summarize briefly, the rabbis seem to conceive of the yetzer hara as generally a bad influence, placed within individuals by God, and to be treated objectively as a thing to be rejected, although the law is seen as a means given by God of controlling it. Apparently, at times attribution is taken from God and given more directly to various human sources when this attribution is thought to be theologically out of character with God's nature.

\section{Original Sin in Paul}

Before turning to a more thorough treatment of the Pauline idea of original sin, it is worthwhile to ask whether there is anything in the rest of the NT similar to the rabbinic concepts of the good and bad impulses. It has been suggested ${ }^{12}$ that several NT phrases reflect such language, including 'for out of the heart

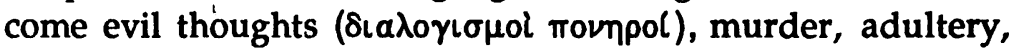

${ }^{11}$ Urbach, Sages 426. See also E. Stiegman, 'Rabbinic Anthropology', Aufstieg und Niedergang der römischen Welt, II.19.2: Religion (Judentum: Palästinisches Judentum), ed. W. Haase (Berlin, de Gruyter 1979) 527-9.

${ }^{12}$ See Tennant, Sources 169. 
fornication, thievery, bearing false witness, blasphemy' (Matt

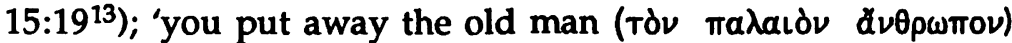
who is being corrupted according to the desires of deceit, ... and put on the new man who is created by God in righteousness and holiness of truth' (Eph 4:22-4); and 'let it not be external adornment, i.e. braiding of hair or wearing gold or putting on of garments, but the hidden person of the heart ( $\delta$ кpumròs Tîs

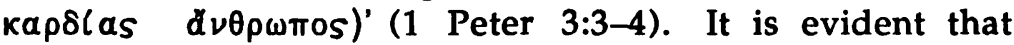
something quite different is being said in these verses than in those passages which refer to the yetzer hara. For one, the opposition here seems to imply that the evil side can be eliminated and replaced by a positive quality, something much more permanent and transforming than the rabbinic picture of constant choice. Second, the NT passages are apparently dealing with several individual parts of a larger whole, whereas the rabbinic concept is a fundamental binary opposition. Even the 'hidden person of the heart' in 1 Peter 3:3-4 appears to be at most the yetzer hatov or good impulse. In none of these cases, however, is the evidence either consistent or sustained enough to warrant equation with the rabbinic concept.

\section{a. Romans 7:7-25}

More important is Romans 7:7-25, treated in detail by W. D. Davies, who sees a very close correlation between Paul and rabbinic thought. ${ }^{14}$ Before considering his analysis of the passage, a methodological observation must be made. Davies appears to overlook an important point regarding use of sources. It is simplistic to feel obligated to say categorically that a writer, in this case Paul, either was or was not dependent upon rabbinic material. One possibility among many others was that while he was aware of, assumed for argument, or even actually endorsed parts of, current thought (if in fact these

\footnotetext{
${ }^{13}$ The parallel in Mark 7:21 is perhaps more noteworthy, since articular of

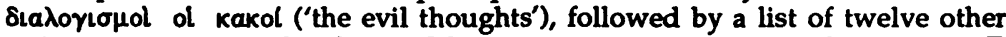
traits, may serve as a headterm. Most commentators recognize this: see esp. E. P. Gould, A Critical and Exegetical Commentary on the Gospel According to St. Mark (Edinburgh, Clark 1896) 132 followed by many since.

${ }^{14}$ Davies, Paul 23-31. Commentators who treat this passage in detail include: Cranfield, Käsemann, Sanday and Headlam, Barrett, Hodge, Wilckens, and most recently Dunn.
} 
ideas were current before $\mathrm{AD} 70$ ), he used, reinterpreted or at the least adapted them for his own purposes. In fact the adaptation and utilization of current thought is the most that can be claimed that Paul is doing in Romans 7:7-25.

Although there are several other plausible outlines, Davies may be correct that Paul divides his life into three parts-a period of innocence (vv. 8-9), a period of commandments (vv. 15ff.), and a third stage of delivery via the Spirit (vv. 25ff.). Davies accepts that this passage is autobiographical. This may be true, but it would need to be in some way representative for Davies's outline of Paul's life to be convincing and for Paul to include it in his letter to a church he had never visited; otherwise, the Pauline experience would be merely a single individual's struggle with some personal evil force and not transferable to the life of every individual. ${ }^{15}$

The first period, innocence, Davies says, would correlate with rabbinic teaching in which a boy reached maturity at the age of thirteen. In Aboth 5.21, Judah b. Tema (AD 150) says, 'At five years old [one is fit] for the Scripture, at ten years for the Mishnah, at thirteen for [the fulfilling of] the commandments, at fifteen for the Talmud ..' (Danby). A major problem with Davies's view is that it was also held in rabbinic circles that the evil influence was given to the individual by God at birth:

Antoninus also enquired of Rabbi [AD 200], From what time does the Evil Tempter hold sway over man; from the formation [of the embryo] or from [its] issuing forth [into the light of the world]?" 'From the formation', he replied. 'If so', he objected, 'it would rebel in its mother's womb and go forth. But it is from when it issues'. (b. Sanhedrin 91b [Soncino])

Not only does this passage call into question existence of an age of innocence, but in Romans 7:8-9 Paul does not seem to have such an age in view. Paul says that he was once alive apart

\footnotetext{
${ }^{15}$ See D. J. Moo, 'Israel and Paul in Romans 7.7-12', NTS 32 (1986) 122-35 who sees the personal as well as representative view in terms of Israel; and C. C. Black II, 'Pauline Perspectives on Death in Romans 5-8', JBL 103 (1984) 425-6 who sees Paul as identifying with the spiritual death of Adam. Cf. D. Patte, Paul's Faith and the Power of the Gospel: A Structural Introduction to the Pauline Letters (Philadelphia, Fortress 1983) 263-77 for an idiosyncratic interpretation.
} 
from the law. It is not entirely certain what this life entails (can it mean only that he was not aware of being a sinner, or that he did not commit sinful acts, as some rabbinic material suggests?) but in the context of Romans 7:9 it implies not an age of unaccountability but life outside of the law's purview.

Regarding the second period, Davies claims that when the boy of thirteen has gone through the bar-mitzvah he becomes morally responsible and fully under the power of the law. As noted above, the law was often seen as the chief agent for conducting battle to resist the evil impulse. Paul might seem to concur with some of this when he says that he would not have known sin except through the law, i.e. when he read commandments that said he should not covet he then knew what coveting was and that he should not do it. But this is a small concession, since Paul proceeds to argue the opposite of rabbinic thought, saying that sin took advantage of the commandments and produced more sin in him, 'for apart from the law sin is dead'. It is when the commandment came that sin came alive and Paul says that he died. Davies claims that the opposition in Paul of flesh ( $\sigma \dot{\alpha} \rho \xi)$ or mind of the flesh ( $\phi \rho \delta \nu \eta \mu \alpha$ Tîs oapкós) versus spirit is Paul's 'translation' of the opposition between the evil and good impulses. Davies is forced to admit, however, that the second element is not an exact equivalent. This points away from seeing the flesh as the evil impulse.

The usual rabbinic placement of the yetzer is in the heart, not the flesh, though it must be remembered that the rabbis did not distinguish these two in the way that the Greeks-and early Christians-did, and that the two were in fact already unified in the OT (Ezek 36:26). It is also noteworthy that any sense of a balance that the rabbis displayed in their treatment, such that one could resist evil and opt for good, is gone from Paul. It seems that Paul's use of flesh here describes a consumptive evil that allows for no internal good which may be chosen. He says as much in verses 15ff.: 'For I do not know what I do; for I do not practice what I want to; but what I hate, that I do'.

The most important point to be made is that Romans 7:7-25 does not appear to be a discussion of the origin of sin, 
whatever else commentators may argue that it is. In rabbinic literature, the theory of the yetzer apparently was the theory concerning the origin and function of sin in humankind. Although Romans 7 is a discussion of sin, and although it occupies an important part of the argument in the book of Romans, it does not seem to constitute an essential part of the theoretical framework of Paul's definition of the origin of sin, even if he identifies himself with Adam. It is also important to note that even if Paul employed the very same concepts as the rabbis in treating the equivalent of the two yetzers (this does not appear to be the case but is asserted for the sake of argument) this would still not constitute an argument for Paul reflecting an identical concept of original sin, since the individual discussions are found within differing contexts.

Paul closes this section of Romans 7 by introducing the role of Christ, an unparalleled element that totally overthrows a rabbinic comparison. The rabbinic literature leaves ambiguous the opposition of the two forces at the end of life. For example, In the time to come the Holy One, blessed be $\mathrm{He}$, will bring the Evil Inclination and slay it in the presence of the righteous and the wicked' (AD 150; b Sukkah 52a [Soncino]) or 'Israel say to the Holy One, blessed be He: 'sovereign of the Universe! Thou knowest the power of the evil inclination, how strong it is!' Said the Holy One, blessed be $\mathrm{He}$, to them: 'Do you dislodge ... him a little in this world and I will remove him from you in the future' (Num. Rabba, Beha'alothecha, 15.16 [Soncino]). Paul entertains no similar idea here, nor does he conceive of a good impulse within the human. He instead introduces the role of Jesus Christ, who sets the wretched person free (vv. 24-5).

So far treatment of Paul's idea of original sin has been negative rather than positive, arguing against lines of correlation between Romans 7:7-25 and the rabbinic concept of the two natures. But if this passage shows Paul's independence of rabbinic tradition on the question of the origin of sin, the natural questions to ask are whether Paul elsewhere develops an understanding of original sin, and if he does, what it is. These questions are not so easy to answer as may first appear. It is noteworthy that in Galatians, a letter so concerned with the history of God's dealings with his people, Paul does not 
specifically address the question of the origin of sin. Galatians 3:15ff., for example, might have prompted some reflection by Paul on the underlying reason for the promise to Abraham and the need for the law. But it does not. Perhaps the specific questions of his opponents or the pragmatic tone of the letter minimizes the importance of the question in this context. In any case, one must turn to 1 Corinthians and Romans to find any sort of statement which defines Paul's concept of sin's origin.

\section{b. 1 Corinthians 15:20-2}

1 Corinthians 15 is concerned with death and resurrection. ${ }^{16}$ Paul seems to have learned that the Corinthians were having trouble with the idea of resurrection, and he deals with the subject in detail, taking up the argument from fundamental principles of the Christian faith, and proceeding to try to persuade them that the idea of resurrection is part of the process of salvation. Paul first recapitulates Christian essentials which he received and passed along to the Corinthians-that Christ died for sins according to the Scriptures, was buried, was raised on the third day according to the Scriptures, and appeared to many, including Paul. This constitutes the basis of Christian faith for him and the other apostles (vv. 1-11).

In the next section Paul switches the approach by attacking the logical inconsistency of an argument that preaches Christ was raised but denies a resurrection, what ever might be substituted in its place. Logically, if there is no resurrection, then Christ was not raised, and Christian preaching is vacuous, since this is an essential element in it. And in fact to preach such would be to misrepresent God as raising Christ when in fact neither he nor anyone else is raised (vv. 12-19).

In the third section (vv. 20-8) - the one that is of direct concern for this paper-Paul turns the argument again, saying that 'but now' (vuvi $8 \xi$ ) Christ is raised (' $\left.\xi^{\prime} \gamma \gamma \in \rho T a L\right)$ from the

${ }^{16}$ Commentators with pertinent discussions include: Héring, Conzelmann, Barrett, Robertson and Plummer, Hodge, and most recently Fee. Recent works which examine many of the important issues are C. E. Hill, 'Paul's Understanding of Christ's Kingdom in 1 Corinthians 15:20-28', NovT 30 (1988) 297-320 although his use of the concept of corporate solidarity is outmoded; and M. C. de Boer, The Defeat of Death: Apocalyptic Eschatology in 1 Corinthians 15 and Romans 5 (Sheffield, Sheffield Academic Press 1988) esp. 93-140. 
dead, i.e. the logic of opponents of the resurrection does not hold in light of the stronger contrary evidence. He is the first fruit or guarantee of the coming 'harvest' of those who are asleep. Paul then introduces verses 21-2, drawing two interwoven analogies: ${ }^{17}$ 'for since through man [there was] death, indeed through man [there was] resurrection of the dead. For as in (the) Adam all die, thus indeed in (the) Christ all will be made alive'. Verse $\mathbf{2 1}$ is usually interpreted as a direct reference to Adam and Christ, but this is probably only seen after reading verse 22. Paul may have been prompted by reference to 'the dead' (v. 20) to make a general statement that death came through $(\delta\llcorner\dot{\alpha})$, or by way of, humankind itself and

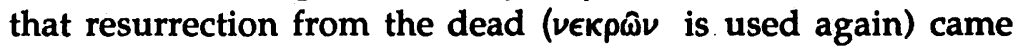
through ( $\left.\delta t^{\prime}\right)$ humankind as well. Perhaps 'Adam', which in Hebrew need not be a personal name but may simply mean 'humankind', lends itself here to verbal play, but in any case Paul seems to ground his argument for Christ as the first fruit in Christ the human being. In verse 22 Paul makes this more

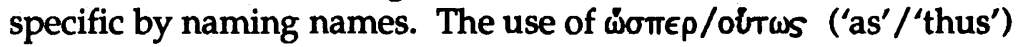
not only gives logical connection to the comparative sentence, but it also connects verse 22 to verse 21 .

Several particular issues may be addressed briefly with regard to the issue of original sin. The assertion that all die, using the omnitemporal present ${ }^{18}$ and the indicative mood, grounds what is observed in human experience in the appropriate grammatical mood for reflecting what is asserted to be the state of affairs: i.e. humans die. The $\xi \nu$ ('in') phrase specifies those who die. It is those in Adam, or in this case 'all'

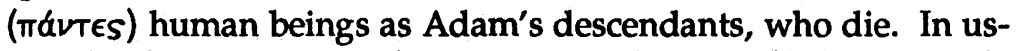

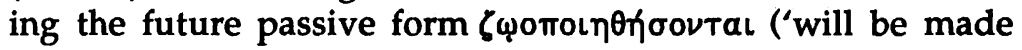
alive'), Paul seems to have realized that there is a difference both in the state of affairs that obtains for humans in Adam,

\footnotetext{
${ }^{17}$ On the double parallelism of vv. 21-2 see G. D. Fee, The First Epistle to the Corinthians (Grand Rapids, Eerdmans 1987) 749-50.

${ }^{18}$ Contra Hill, 'Understanding' 304 citing H.-A. Wilcke, Das Problem eines messianischen Zwischenreichs bei Paulus (Zürich/Stuttgart, 1967) 67 who claims it is a timeless present. The fact that a process of nature is referred to indicates that it is an omnitemporal present. On this terminology see $S$. E. Porter, Verbal Aspect in the Greek of the NT, with Reference to Tense and Mood (New York, Peter Lang 1989) chs.. 2 and 4.
} 
i.e. they are dying, and in the state of affairs for those in Christ. Christ is the first fruit of what is still expected, hence the form of expectation — the future form-is used. ${ }^{19}$ MávTes in this clause is also defined by contextual and grammatical factors. The $k \nu$ phrase again delimits those who will be made alive. Those who are in Christ, i.e. Christians can look forward to being made alive, even though once dead. ${ }^{20}$

The second major issue is what is meant by in

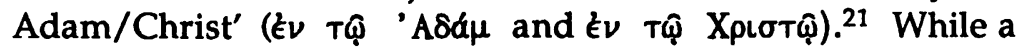
few scholars argue that presence of the article assumes that Paul believed in a historical Adam and a historical Christ, ${ }^{22}$ it is linguistically dubious that the article in Greek alone can prove this point. The article instead seems here to denote definiteness. ${ }^{23}$ Nevertheless, it appears that Paul thought of Adam as a historical figure on the basis of his argument, which depends upon the work of particular individuals in particular spheres at particular times. But the parallelism is not exact. It is an observable fact that humans die, thus it is less important that there is a historical figure behind this event; for the ${ }^{19}$ See Porter, Verbal Aspect ch. 6 on the future as grammaticalising
expectation.
${ }^{20}$ See M. Holmes, 'Paul's Soteriological PAS: Universal or Limited? An Examination of Three Pauline Texts', Trin J 6 (1977) 157 who argues that $\zeta \psi_{0} 0 \pi \operatorname{tat}^{\omega} \omega$ refers to supernatural and not revivificational life; and Fee, Corinthians 747 n. 5, 749-50 on 'all'.

${ }^{21}$ On the $E \nu$ XpLoTQ phrase see most recently A. J. M. Wedderburn, 'Some Observations on Paul's Use of the Phrases "in Christ" and "with Christ", JSNT 25 (1985) 83-97.

${ }^{22}$ See e.g. A. Robertson and A. Plummer, A Critical and Exegetical Commentary on the First Epistle of St. Paul to the Corinthians (Edinburgh, Clark, 1914²) 352 note $t$. For a recent introduction to the supposedly coherent body of material that grew up around reflection upon Adam see J. D. G. Dunn, Christology in the Making: A NT Inquiry Into the Origins of the Doctrine of the Incarnation (Philadelphia, Westminster 1980) 98-128. An analysis and critique is found in N. T. Wright, 'Adam in Pauline Christology', Society of Biblical Literature 1983 Seminar Papers, ed. K. H. Richards (Chico, California, Scholars Press 1983) 359-89; cf. also Hill, 'Understanding' esp. 304-05 nn. 16-18. My own impression is that development of a unified and sustained myth about Adam cannot be shown to have existed in the 1st century world. In support of this contention see J. R. Levison, Portraits of Adam in Early Judaism: From Sirach to 2 Baruch (Sheffield, Sheffield Academic Press 1988) esp. 13-31.

${ }^{23}$ Of course the article can be used in Greek to mark generic use, but that runs contrary to Paul's argument here. 
resurrection the situation is different, since Christ's resurrection is the guarantee of a later transformation of life. The $k \nu$ is

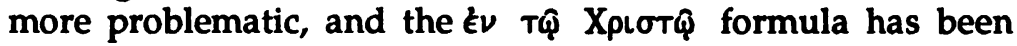
subject to great debate. A spherical use is not implausible (it need not have the traditional connotations of corporate solidarity $\left.{ }^{24}\right)$, and seems to work well in relation to the preceding $8 \mathrm{id}$ ('through'). Paul would then be saying that just as death and resurrection entered by means of humankind, thus, within the respective spheres of Adam as the bringer of death and Christ as the bringer of resurrection, humans die or are made alive. ${ }^{25}$

An unarticulated point in the argument-and yet one that calls for comment, since the reality of death lies behind Paul's argumentation-is how it is that death entered. There are various proposals noted in the secondary literature. Some scholars have posited hellenistic or gnostic background, in which Adam is a heavenly man who descends to earth, takes on a physical body, and then redeems humankind, which is in some way identified corporately with him. Seyoon Kim has shown that this complex of ideas is not present here in 1 Corinthians or in Romans 5:26 Paul believes that the origin of Adam and Christ is in the human realm, i.e. in the realm of history and not mythology; Paul holds that the resurrection for believers has not yet occurred but is still being anticipated; Paul denies the universality of resurrection for all who are

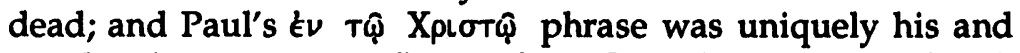
pre-dated any gnostic influence from Corinth. Also, use of such language and concepts as 'corporate personality' must be reconsidered in light of recent trenchant criticism. ${ }^{27}$ A much more likely source for Paul's argument seems to be the OT itself, especially Genesis 3. (Perhaps Paul's reflection in 15:45 on Gen 2:7 is further support for this.)

${ }^{24}$ See C. F. D. Moule, The Phenomenon of the NT (London, SCM 1967) 21-42 esp. $23,29$.

${ }^{25}$ See C. H. Dodd, The Interpretation of the Fourth Gospel (C.U.P. 1953) 18792.

${ }^{26}$ S. Kim, The Origin of Paul's Gospel (Tübingen, Mohr [Siebeck], 1981) 162-79.

${ }^{27}$ See esp. J. W. Rogerson, "The Hebrew Conception of Corporate Personality: A Re-Examination', ITS 21 (1970) 1-16; and S. E. Porter, 'Two Myths: Corporate Personality and Language/Mentality Determinism', S/T (in press). 
Several discussions of the origin of Paul's thought on this issue refer to Jewish sources. ${ }^{28}$ Establishing such lines of influence is difficult and in many cases counterproductive. One of the passages forming the underpinning of many a Jewish view is Ben Sira (Eccl) 25:24, which is said to attribute to Eve the origin of sin and death. Rarely if ever is the entire context of this verse noted. Verse 24 is in the midst of a larger discussion of 'bad wives' (25:13ff), which reads:

There is nothing so bad as a bad wife; may the fate of the wicked overtake her! It is as easy for an old man to climb a sand-dune as for a quiet husband to live with a nagging wife. ... If a man is supported by his wife he must expect tantrums, shamelessness, and outrage. A bad wife brings humiliation, downcast looks, and a wounded heart. Slack of hand and weak of knee is the man whose wife fails to make him happy. *Woman is the origin of sin, and it is through her that we all die.* Do not leave a leaky cistern to drip or allow a bad wife to say what she likes. If she does not accept your control, divorce her and send her away. (NEB)

If the context alone does not cast a reasonable doubt upon the usual reading, ${ }^{29}$ then the argument that the passage refers to evil wives who have a devastating effect on their husbands may prove persuasive. ${ }^{30}$ The verse would read something like, 'a wife is the origin of sin, and it is through her that we husbands all die'. This is not to say that this passage may not refer or allude to Eve, only that such a position must be argued for much more stringently, and not assumed as a central plank for historically reconstructing the background to Paul's concept of sin.

The only reasonable certainty is that Paul has Genesis in mind, though this is not without its difficulties. 1 Corinthians 15:22 would suggest that Paul is tacitly introducing

${ }^{28}$ See A. L. Thompson, Responsibility for Evil in the Theodicy of IV Ezra: A Study Illustrating the Significance of Form and Structure for the Meaning of the Book (Missoula, Montana, Scholars Press 1977) 5-82 for a survey of passages.

${ }^{29}$ E.g. J. G. Snaith, Ecclesiasticus, or The Wisdom of Jesus Son of Sirach (C.U.P. 1974) 129-30.

30J. Levison, 'Is Eve to Blame? A Contextual Analysis of Sirach 25:24', CBQ 47 (1985) 617-23. Contra P. W. Skehan and A. A. Di Lella, The Wisdom of Ben Sira (New York: Doubleday, 1987) 348-9 who nevertheless are much more moderate in their interpretation. 
sin on Adam's part as the root cause of death. A question raised is whether death existed before Adam's sin, and whether Paul was aware of this. Robertson and Plummer argue that death existed before Adam's sin, but that death as the punishment for sin was introduced when Adam sinned. ${ }^{31}$ This may or may not be true (and may well apply differently to humans and nonhumans), but it goes beyond what Paul says. He attributes death to Adam and life to Christ (vv. 21-2). He does not elucidate why it is that all people die 'in Adam'. Either Paul assumed a particular explanation, in which case there is no clear source for it, or better still a more exact mechanics did not occur to him here. It must have seemed to be the way things are for all people, who in some way are 'in' $(\xi \nu)$ the man who introduced death ( $\delta \iota^{\prime}$ ' $\nu \theta \rho \omega$ mov $\theta$ divatos) and thus required the later life-giving act of Christ. The reference is but a small part of his argument, and he continues with a discussion of the events surrounding the end of time. Paul again refers to Adam in verse 45 , but here the discussion is of the resurrection body and is not directly relevant to speculation on the origin of sin.

\section{c. Romans 5:12-21}

Whereas the reader might want Paul to develop further his comparison of Adam and Christ in 1 Corinthians, Paul apparently did not feel it necessary for his argument. And certainly the argument works without it. What is more noteworthy perhaps is Paul's lack of explicit comparison of Adam and Christ in the early chapters of Romans. While Paul and his audience may have shared a common conception of the origin of sin (although there is no clear textual indication), and Paul may have wanted to clarify certain issues first (there is a striking unity to Romans 1-4), it is significant that Paul felt com-pelled to elucidate the theory in some detail in Romans 5:12-21.

Romans 1:18-3:20 is the first major section in Paul's argument that the Gospel reveals righteousness (1:16-17). He first establishes the necessity; simply put it is that all humans are ungodly and unrighteous, and hence divine wrath is revealed against them. In 1:20, Paul refers to the fact that

${ }^{31}$ Robertson and Plummer, 1 Corinthians 352. 
'since the creation of the world His invisible attributes ... . have been clearly seen, being understood through what has been made, so that they are without excuse' (NASB). Here would seem a logical place for Paul to introduce reference to Adam, or at least some firm allusion to a theory of the origin of sin in relation to creation, especially since he refers to humankind's lost glory in 1:23. But no obvious explication is forthcoming. ${ }^{32}$ Perhaps at this stage Paul did not feel the necessity, since he is in the midst of a different sort of argument, that is, establishing not what humanity has for an inheritance as part of the human race, but how each human perverts what truth it has. Throughout this section there is an emphasis upon God's known presence being consciously denied until such a point where God 'gives' humans over to their lustful hearts (1:24). Every human, 2:1 says, is without excuse and subject to God's judgment, whether Jew or Gentile, with or without the law.

This eventually raises the question in 4:1-5:21 of how to mediate the gulf between human and God, answered by showing that even Abraham was justified by faith. And just as Abraham was justified, so other humans might not only be justified but enter into a peaceful relationship with God, i.e. be reconciled to him. Romans 5:12-21 therefore is a summation, ${ }^{33}$ in which Paul articulates the vital connection between the origin of humankind's condition which he has been describing and the place and importance of the work of Christ. Paul is conspicuous in his lack of theoretical grounding and establishment of the cause of human depravity in 1:13ff. At points the language in 1:18ff. and 3:23 may be similar to Genesis

${ }^{32}$ Several scholars have argued for varying degrees of reference to Adam in 1:18ff. and 3:23: M. D. Hooker, 'Adam in Romans 1', NTS 6 (1959-60) 297-306; idem, 'A Further Note on Romans 1', NTS 13 (1966-7) 181-3; C. K. Barrett, From First Adam to Last: A Study in Pauline Theology (London, Adam and Charles Black 1962) 17-19; Dunn, Christology 101-03. These views are examined by A. J. M. Wedderburn, 'Adam in Paul's Letter to the Romans', Studia Biblica 1978. III. Papers on Paul and Other NT Authors, ed. E. A. Livingstone (Sheffield, JSOT 1980) 413-30.

${ }^{33}$ Cf. G. Bornkamm, Das Ende des Gesetzes: Paulusstudien (Munich, Kaiser 1952) 80ff. who, although he considers 5:12-21 an anacoluthon, notes points of connection. 
1-3, but Paul does not present any explicit theory until 5:12ff. ${ }^{34}$ Perhaps a brief allusion to creation (if in fact this is present) prompted further cerebration upon the reason for humankind's apparently total and complete turning from God. In 5:1-11 Paul has stressed that it is the work of Jesus Christ that has been the vehicle for humanity's new relationship with God, and it is likely that his further reflection upon the wholly beneficial work of a single individual prompted him to contemplate the story of another figure who in fact had quite a different effect upon the human race.

A brief description of Paul's major line of thought will provide the vehicle for treating in some detail his views of original sin..$^{35}$ sid TovTo ('because of this', v. 12). The proposal that this logical connective refers forward ${ }^{36}$ falters on the fact that it is not supported by an apparently mandatory purpose or causal clause (cf. Rom 4:16). ${ }^{37}$ Besides, this would create an uncomfortable splitting off of a section that cries out for connection with what has preceded. As Sanday and Headlam have indicated, whether the exact reference of the connective is verse 11 , verses $9-11,5: 1-11$, or $1: 17$ onwards is difficult to determine, but 'it seems natural to include at least as much as contains a brief outline of [the work of Christ and Adam], i.e. as

${ }^{34}$ In fact, Hooker 'Adam' 306 says, 'the reference to Adam is made explicit only when we come to chapter $\mathbf{v}^{\prime}$.

${ }^{35}$ The most helpful commentaries at this point are Cranfield, Hodge, Barrett, Sanday and Headlam, Käsemann, Black, and J. A. Fitzmyer, The Letter to the Romans', The Jerome Biblical Commentary, ed. R. E. Brown et al. (London, Geoffrey Chapman,1968) 53:52-9.

${ }^{36} \mathrm{C}$. K. Barrett A Commentary on the Epistle to the Romans (London, Adam and Charles Black, 1957) 110) suggests but does not endorse this view, which is accepted by, among others, E. Brandenburger, Adam und Christus: ExegetischReligionsgeschichtliche Untersuchung zu Röm 5:12-21 (1 Kor 15) (Neukirchen, Neukirchener 1962) 258-9; O. Michel, Der Brief an die Römer (Göttingen, Vandenhoeck und Ruprecht 1978) 138.

37C. E. B. Cranfield, 'On Some of the Problems in the Interpretation of Romans 5.12', SJT 22 (1969) 324-6. Cf. M.-J. Lagrange, Saint Paul: Epitte aux Romains (Paris, Gabalda 1950) 105 who calls it a literary transition. 
far as verses $1-11^{\prime} \cdot{ }^{38}$ Verse 12 is constructed in chiastic fashion, with four separate elements. 39

Verse 12a. Just as through one man sin entered into the

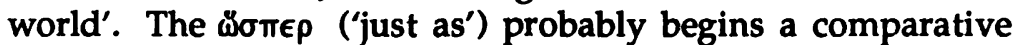
clause that is broken off at the end of verse 12 and not continued until verse 19. This anacoluthon emphasizes the parenthetical material in verses 13ff., although the alternative suggestion that the kal outws ('and so') completes the construction is plausible conceptually but probably not grammatically. ${ }^{40}$ The \&ld ('through') phrase is reminiscent of 1 Corinthians 15:21, but this time évos ('one') specifies the d $\nu \theta p \omega$ orov ('man'), so that Adam need not be stated but is understood. Sin (note the generic

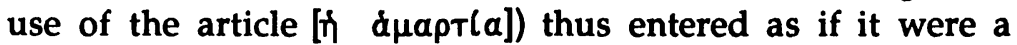
'person' into the world. The temporal reference is probably past on account of the allusion to Adam, with 'world' (Tdv

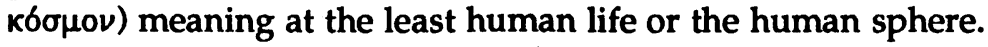

Verse 12b. 'And through sin, death'. Paul uses 'sin'

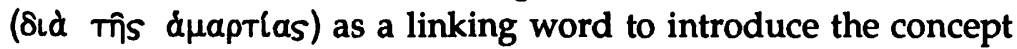
of death entering into the world. Paul has already gone beyond his brief exposition in 1 Corinthians 15:21-2 by making a connection between sin and death. The one man was the channel for sin to enter, and sin was the channel for death. A pertinent question is what kind of relationship Paul saw between the one man and death-is it a two-stage causal relation (Adam brought sin, and sin brought death), or is death a concomitant circumstance of sin (Adam brought sin and death)? Although the former is more likely (cf. Rom 6:23), Paul does not seem

${ }^{38} \mathrm{~W}$. Sanday and A. C. Headlam, A Critical and Exegetical Commentary on the Epistle to the Romans (Edinburgh, Clark 19025) 131.

${ }^{39}$ Brandenburger, Adam 175 n. 1; cf. A. J. M. Wedderburn, The Theological Structure of Romans V.12', NTS 19 (1972/73) 339-54 for a survey of background issues. He endorses Jewish as opposed to gnostic thought, although he is at times overcome by parallelomania.

${ }^{40}$ See C. E. B. Cranfield, A Critical and Exegetical Commentary on the Epistle to the Romans, 2 vols. (Edinburgh, Clark 1975, 1979) 1.272 and most commentators; contra Barrett, Romans 109-10; R. Scroggs, The Last Adam: A Study in Pauline Anthropology (Oxford, Blackwell 1966) 79-80; B. Englezakis, 'Rom 5:12-15 and the Pauline Teaching on the Lord's Death: Some Observations', Bib 58 (1977) 232; J. T. Kirby, 'The Syntax of Romans 5.12: A Rhetorical Approach', NTS 33 (1987) 283-6; cf. de Boer, Defeat $158 \mathrm{ff.}$ 
concerned here to specify; ${ }^{41}$ in either case sin and death in the world are implied as penal results of the first man's action.

Verse $12 \mathrm{c}$. 'And so death passed through [ $\delta\llcorner\hat{\imath} \lambda \theta \epsilon]$ to all men'. kal oftws ('and so') marks the next logical step in the argument. Whereas one man sinned and through his sin death entered the world, also then death permeated all. The use of $\delta\llcorner\dot{\alpha}$ prefixed to $\hat{\eta} \lambda \theta \epsilon$ may mean nothing more than that death spread, in which case only selected individuals may have been affected, but it may also mean that death permeated human life. On the basis of Paul's subsequent argument, the more emphatic or intensive use is probably present here.

Verse $12 \mathrm{~d}$. ' $\epsilon \phi$ ' $\Phi$ all sin(ned).' The $\xi \phi$ ' $\$$ clause has been widely disputed. The chiastic construction seems to reinforce that the clause is not strictly redundant in the sense that, since Adam's sin introduced death, it makes no difference whether others sin. ${ }^{42}$ The point seems rather to be that there is a relation between Adam's sin and the sin of all human beings. Even if this is agreed, there are still several different possible lines of interpretation that might be pursued. ${ }^{43}$

$\xi \phi$ ' ${ }_{\varphi}^{\tau}$ meaning 'in which', with $\Phi$, masculine, referring to an implied law ( $\nu 6 \mu \rho s) .{ }^{44}$ Danker's contention is that all, including Gentiles, have sinned, breaking a legal obligation. This does not make sense of Paul's argument, which is not concerned here with the matter of law, $\nu 6 \mu o s$, not being used in verses 1-11 (Danker explicitly dismisses use in v 13 as its

${ }^{41}$ Can both be possible? See Black, 'Pauline Perspectives on Death' 420-1.

${ }^{42}$ The position that Adam's sin makes post-Adamic sin superfluous is held by R. Bultmann, 'Adam and Christ According to Romans 5', Current Issues in NT Interpretation: Essays in Honor of O. A. Piper, ed. W. Klassen and G. F. Snyder (London, SCM 1962) 152-3.

${ }^{43}$ Excellent summaries and analyses of those who hold to various positions may be found in Cranfield, Romans 1.274-81; idem, 'On Some of the Problems' 330-40; S. L. Johnson, Jr., 'Romans 5:12-An Exercise in Exegesis and Theology', New Dimensions in NT Study, ed. R. N. Longenecker and M. C. Tenney (Grand Rapids, Zondervan, 1974) 303-13; cf. E. Käsemann, Commentary on Romans (ET Grand Rapids, Eerdmans 1980) 147-9 who is highly suggestive. For discussion of patristic thought see $\mathrm{H}$. Rondet, Original Sin: The Patristic and Theological Background (ET Staten Island, New York, Alba 1972) $25 \mathrm{ff}$.

${ }^{44}$ F. W. Danker, 'Romans V.12. Sin under Law', NTS 14 (1967/68) 424-39; cf. idem, 'Under Contract: A Form-Critical Study of Linguistic Adaptation in Romans', Festschrift to Honor F. W. Gingrich, ed. C. H. Barth and R. E. Cocroft (Leiden, Brill,1972) 104-05. 
referent). Neither is his reference to other Pauline uses of $\epsilon \phi^{\prime} \Phi$ as conveying a 'formal contractual basis' borne out in context ( 2 Cor 5:4; Phil 3:12; 4:10). Just as unlikely is reference to 'death'. Not only does it make the final clause redundant in such an obviously semantically full and balanced construction, but it seems to invert the order of events of sin and death in a mandatory two-stage process, with sin coming on account of death and with death limited to a purely spiritual sense.

$\epsilon \phi^{\prime} \uparrow$ meaning 'in whom', with $\Phi$ masculine, referring to 'one man."45 This interpretation fails because of the distance from the antecedent in verse $12 a$ and because $z \nu$ ('in') would be the more likely preposition, especially since locative $\xi \pi l$ tends to refer to physical location. None of Paul's uses (2 Cor 5:4; Phil $3: 12 ; 4: 10)$, or the other NT usage (Acts 7:33), of $\xi \phi^{\prime} \Psi$ has this meaning. This appears to have been Augustine's understanding, ${ }^{46}$ was embodied in the Vulgate's in quo, and has had an influential history in biblical interpretation. While it may be true that humanity was in some way 'in' Adam (realist and federalist theologians would define this relation in different ways, see below), Augustine's view is not textually well-based in this instance, and this factor should not be overlooked. That Augustine's interpretation was probably based upon a misunderstanding of the grammar, and that later supporters have relied upon vague concepts of corporate personality in this view's defense, should make modern scholars very hesitant to use his position without substantial re-examination (if it is not rejected outright).

$\$$, masculine, referring to 'one man', but $\xi \pi l$ meaning 'because'. ${ }^{47}$ Although the causal sense is probably correct, this position fails primarily because of the distance from the antecedent (see above) but also because the argument would be

45 Lagrange, Romains 106-07; N. Turner, Grammatical Insights (Edinburgh: Clark 1965) 116-18; H. Lietzmann, Einführung in die Textgeschichte der Paulusbriefe an die Römer (Tübingen, Mohr [Siebeck] 197155) 61-2.

46 See G. Bonner, 'Augustine on Romans 5, 12', Studia Evangelica V, Part II: The NT Message, ed. F. L. Cross (Berlin, Akademie, 1968) 242-7.

47 J. Cambier, 'Péchés des hommes et péché d'Adam en Rom. V.12', NTS 11 (1964-5) 253-4. 
out of character with the major emphasis of the rest of the verse, as well as the rest of the passage, upon sin and death.

$\xi \phi ' £$ meaning 'because', possibly as an assimilation of classical $k \pi l$ Tout@ $8 T L, 48$ although it is of little value whether this is its basis, since synchronic usage is more important than diachronic history. While $\xi \pi l$ may have a locative sense, this is often reserved for physical location, but a causal sense for the conceptual realm is well attested in classical through to hellenistic Greek. Although there are a few interpreters who still argue for the Augustinian or some other interpretation, the majority opt for a variant of this choice, although there are two possible senses of the causal understanding: resultant and effective. According to the resultant sense, clearly endorsed by most commentators, ${ }^{49}$ sin entered into the world and with it death, and death spread to all people 'on the basis of which' all sinned, emphasizing the chiastic structure of verse 12 and the concomitant action of the one man and the many in sinning. According to the effective sense, the understanding is that sin entered into the world through one man, and with it death which spread to all people, 'on which basis' all sinned. ${ }^{50}$ For most commentators it is not crucial to distinguish these two senses, although the effective may be a better approximation of Paul's understanding of the phrase, placing the resultant actions of the many as predicated upon the action of the one.

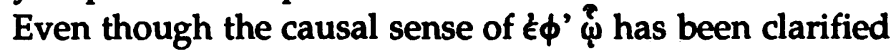
there remains the major question regarding the referent of

${ }^{48}$ See F. Blass and A. Debrunner, A Greek Grammar of the NT and Other Early Christian Literature (ET Chicago, Univ. of Chicago Press 1961) ๆ 294 (4); cf. ๆ 235 (2).

${ }^{49}$ E.g. Sanday and Headlam, Käsemann, Cranfield, Bruce, Murray, Barrett, Schlatter, Althaus, Dodd, Meyer, Wilckens, Michel, Dunn, Brandenburger, and such grammarians as Winer, Moulton, and Moule.

50 This view is held by S. Lyonnet, 'Le sense de ' $\xi \phi$ ' $\$$ en Rom 5:12 et l'exégèse des Pères grecs', Bib 36 (1955) 436-56 esp. 454-6; idem, 'Le péché originel et l'exégèse de Rom 5:12-14', Saint Paul: Epître aux Romains by J. Huby, ed. S. Lyonnet (Paris, Beauchesne, 1957) 534-8; Englezakis, 'Rom 5:12-15' 232; M. Black, Romans (London, Oliphants 1973) 88-9. 


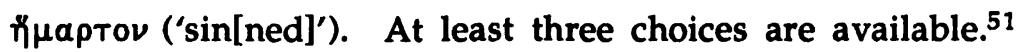
First, గn after Adam's example. This probably was Pelagius' view, and results in a gloss something like: because all sinned after

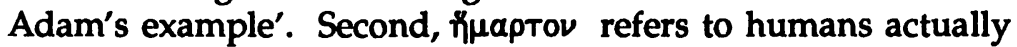
sinning in Adam. In other words, when Adam sinned, all of his descendants sinned as well in his sinful act. This has been called the realist view, and is actually a modification of the

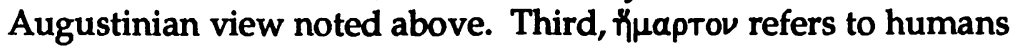
actually sinning because they were constituted sinners as a result of Adam. In other words, when Adam sinned, he sinned as the legal representative of his race, who are also counted guilty of his first sin (federalist view).

Reference to 'all' ( $\pi d v T \epsilon S$ ) does not clarify whether Paul understands $\eta_{\mu \alpha \rho}$ Tov in any of the three alternatives. While it may well be true that many people sin by following the example of others, and the Pelagian view emphasizes the importance of responsible behaviour, it also has the most difficulty with this verse, since death, the result of sin, is a universally attested phenomenon of the human world. It would appear that even those who do not follow the example of Adam in sinning suffer the same consequence, death. A further difficulty of the Pelagian view is that it must force the grammar unnaturally. The realist would contend that 'all' is an accurate literal statement that in fact every single individual did sin in Adam's first sin. This appears, however, to overstress interpreting the aorist verb form as punctiliar and past-referring, when it is probably an omnitemporal statement referring to past, present and future events (cf. Rom 3:23). The federalist would claim that whereas it could be argued that not every individual actually sins (e.g. infants), every individual as part of humanity with Adam as its designated head therefore is constituted a sinner. There is a recognizable tension here in Paul between destiny and individual action, ${ }^{52}$ but at this point Paul is not more specific.

\footnotetext{
51 See L. Berkhof, Systematic Theology (Grand Rapids, Eerdnians 1941) 240-3 for a helpful analysis of the major positions in systematic theology on the origin of sin.

52Cf. Käsemann, Romans 147; de Boer, Defeat 160-1.
} 
Paul apparently sensed the importance and complexity of the material he was presenting, as well as the potential

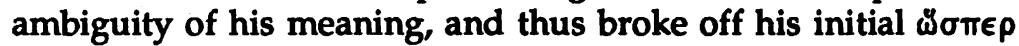
('just as') construction in order to clarify several points raised in verse 12. In any case he never returns to the exact grammatical construction. Instead he restates the protasis in verse 19 and then completes the construction by moving straight to the issues of justification and law, with a final summary in verse 21 .

Verses 13-14. In verse 13 Paul makes the rather puzzling comment, especially in light of Romans 2:14ff., that 'until the law sin was in the world, but sin is not counted where there is no law'. The fact that sin was in the world is attested by the fact that humans died before the giving of the law, here referring to the Mosaic code. The verb E $\lambda_{0}=\gamma \in \hat{\imath} T a \mathrm{l}$, translated 'counted', should probably mean here something close to 'being charged to one's account," 53 as when there is an explicit law that makes it evident that sin has been committed. Paul continues in verse $\mathbf{1 4}$ by saying that in fact it is not as if there were no sin, but ( $\alpha \lambda \alpha \dot{)}$ ) death ruled from Adam until Moses. As in verse 12 , death is again personified as not merely alive but as a figure of power and authority. Again the question is inadvertently raised whether Paul believed there was no death before Adam's sin. Whether Paul distinguished between death for humans and non-humans before the fall is unknown, but the probability is that Paul thought of Adam as not knowing death before the fall. This point cannot be pushed, however, since Paul's major emphasis is to establish the relation between sin and redemption through the actions of two figures, Adam and Christ. Paul says that death even ruled over those who did not sin in the likeness of the mapaßdoews ('sin, disobedience') of Adam, who is the type of the coming one. Those few textual variants that eliminate $\mu$ ' ('not') with the participle duaptifoavtas ('sin') have surely missed the point, and that is that in fact Adam's violation was differentand by implication worse- than the sin of those who followed, although this cannot be taken as a direct endorsement of either

${ }^{53}$ See W. Bauer, A Greek-English Lexicon of the NT and Other Early Christian Literature, trans. and ed. W.F. Arndt et al. (Chicago, Univ. of Chicago Press,19792) 252. 
the federalist or the realist views. For each, Adam's sin was categorically different from subsequent humankind's. For the realist Adam's first sin was the condemnatory sin for every human being, although it must be granted that this view has difficulty explaining why subsequent sin was not equally detrimental and corrupting. For the federalist the guilt of Adam's sin was determinative for the subsequent condemnation of humankind, i.e. his act entailed legal consequences for those under his federal headship. Use of mapaßaris seems to point to the particular violation of a specific commandment or injunction, quite probably an allusion, therefore, to the Genesis account of the fall (Gen 2:17; cf. 1 Cor 15:22).

The relative clause in verse 14 appears designed to remove all doubt regarding the correlation between Adam and Christ-Adam was a type of the one coming (To0 $\mu \in \lambda$ Aovtos), that is Christ. ${ }^{54}$ The use of 'type' does not mean, of course, that the individual elements need be identical at every point, since Paul says at several junctures that Christ exceeded Adam in virtually every way, but that one prefigures the other, Adam as head of a sinful people, and Christ as head of those justified. The Pelagian view of Adam's sin as an example has its firmest basis in this phrase, although those who hold this view apparently must significantly alter the sense of 'type'. So far the explicit lines of connection between Adam and Christ are not numerous, although Paul is obviously drawing together strands of his argument from chapters 1-5:11. Certainly the role of Adam and his introduction of sin and death point to a large task for one who would undo this.

Verses 15-18. Here the disproportionate comparison of Adam and Christ is drawn, through a series of comparative clauses. ${ }^{55}$ Two major points summarize what Paul is saying.

${ }^{54}$ L. Goppelt, Typos: Die Typologische Deutung des Alten Testaments im Neuen (Darmstadt, Wissenschaftliche, 1966) 155-6; contra e.g. Scroggs, Last Adam 801. Although there have been other proposals for To0 $\mu k \lambda$ ovTos, such as Moses or Noah, these are more fanciful than substantial.

${ }^{55} \mathrm{C}$. C. Caragounis ('Romans 5.15-16 in the Context of 5.12-21: Contrast or Comparison?' NTS 31 [1985] 142-8) argues that vv. 15a and 16a should be rendered as rhetorical questions expecting positive answers, followed by conditional sentences which reinforce the comparison of Adam and Christ. His 
First, Adam's transgression ( $\pi \alpha \rho \alpha \pi T \omega \mu \alpha)$ or sin in some way brought death to many (vv. 15, 17). Paul restates the same essential point several different ways. In the first he states the simple result of Adam's sin, taking évós ('one') as masculine, although even if it is neuter, reference to 'one sin' is surely to Adam's: the result is that many died (v. 15), with 'many' here meaning 'as opposed to one or none'. But in the second restatement, after an identical protasis Paul reintroduces personified death as reigning (v. 17). Thus a firm connection is established between the sin of Adam, or the first sin, and death's powerful presence in subsequent generations. The grammar at this point is not any more specific, since the conditional clause posits a logical relation between protasis and apodosis, nothing more. ${ }^{56}$

Second, the one transgressor was also responsible for the judgment and condemnation of many (vv. 16, 18). If above there was any doubt whether death was physical or spiritual, these statements by Paul show that he sees it as spiritual as well as physical. ${ }^{57}$ In parallel clauses, verse 16 says that the judgment of the one man (taking évos as masculine, the same as v. 16a) led to $(\epsilon l s)$ condemnation, and grace from many transgressions-presumably of those who followed Adam-led to ( $\mathrm{kls}$ ) justification. Although the noun katákpı $\mu \alpha$ ('condemnation') is anarthrous and without any possessive indicator, it apparently refers not only to Adam but to all humankind judged as condemned. In verse $\mathbf{1 8}$ the relation between the two is made even more explicit, when Paul says that, therefore/thus ( $\AA_{p \alpha}$ ozv), the result ( $\epsilon l s)$ of one man's ( $\varepsilon v \delta s$ is masculine here, too) misdeed is that all are condemned. While it might be argued that Paul's separation of the sin of one man from the many sins of others (v. 16b) points to a federalist view, in that these sins came as a result or after the sin of Adam, this is not entirely

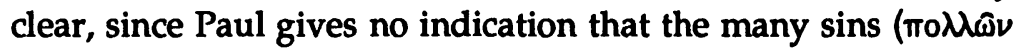

argument is convincing, and is now also supported by $\mathrm{H}$. Sahlin, 'AdamChristologie im NT', ST 41 (1987) 32 n. 18.

56 See Porter, Verbal Aspect ch. 6 on conditional statements.

${ }^{57} \mathrm{Cf}$. T. Barrosse, 'Death and Sin in Saint Paul's Epistle to the Romans', CBQ 15 (1953) esp. 453ff. although he greatly overstresses the supposed contrast between the Semitic and Greek minds. 
$\pi \alpha p a \pi T \omega \mu \alpha+\tau \omega \nu)$ are to be treated as something completely distinct from the sin of Adam (Evòs duaptrfoavtos). To the contrary, Paul is arguing that the gift of grace exceeds the one man's sin (vv. 15, 17) and brings justification from all transgressions to all (vv. 16, 18) who receive this rich gift (v. 17).

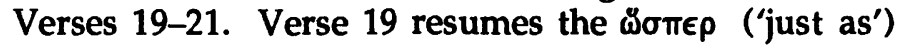
clause of verse 12,58 although this time Paul alters the protasis to make the entire statement a summary of his previous discussion. The protasis, balanced by the apodosis beginning with outTws kal ('thus'), includes the significant elements of the comparison between the work of Adam and Christ. Just as the disobedience (mapakor) of the one man was the channel ( $\delta\llcorner d)$ for many to be made sinners, the obedience (imakor) of one, i.e. Christ, was the channel $(\delta\llcorner\alpha)$ for many to be made

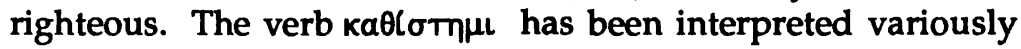
from a weak sense of 'become', taking the verb as middle voice, to the stronger sense of 'prove to be', to the strongest 'make' or 'cause to be placed', the last stressing the passive voice with agency $(\delta\llcorner\alpha) .59$ The force of Paul's argument, throughout Romans but especially in 5:12-18, seems to require the strongest sense, quite probably with juridical connotations which continue the tone of the entire passage. ${ }^{60}$ Something happened when the first man sinned that made all humankind to be

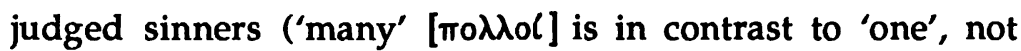
opposed to 'others"), something so ineluctably bad that it could only be rectified by the obedience of a second man, and thus many were judged to be righteous. The parallelism is forceful. Both federalist and realist theologians find nothing to contradict their theories in this verse, since both acknowledge the role of Adam and his disobedience, and the role of Christ and his obedience, although the federalist view is more compatible with the juridical language here and throughout

\footnotetext{
${ }^{58}$ Despite the use in v. 18 of $d p a$ orv (which I take as an introduction of the comparison of v. 18 alone; cf. K. W. Clark, The Meaning of APA', Festschrift to Honor F. W. Gingrich 79), it is more reasonable to take v. 19 as the continuation of v. 12. Cranfield (Romans 1.288-91) hints at this understanding; cf. de Boer, Death 162-63 who sees a close connection between vv. 12 and 21 .

${ }^{59}$ Cf. Bauer, Lexicon 390.

${ }^{60}$ Danker, 'Under Contract' $106-07$.
} 
Romans. At this point Paul seems to leave the conflict of verse 12 over the $\xi \phi^{\prime} \varphi^{\prime}$ clause, and reintroduces the law as a prelude to impelling forward the major thrust of his discourse in 6:1.

This section has argued both that Paul is independent of the rabbinic formulation and conceptualisation of the origin of sin, and that he puts forward his own view of sin's origin in 1 Corinthians 15:20-22 and especially Romans 5:12-21. Regarding Romans 7:7-25, while the supposed influence of the rabbinic concept of the two natures has had widespread appeal among scholars, close analysis discounts the importance of rabbinic thought here, as well as a significant role for this text in Paul's formulation of a concept of sin's origin. 1 Corinthians 15:20-22 posits a parallel relation between the work of one man, Adam, in bringing death to all, and the work of another man, Christ, in bringing life, although what it means to be 'in' Christ or Adam is not fully elucidated. In Romans 5:12-21 Paul develops his concept of sin's origin, showing that sin and death came as the result of Adam's sin, and this entailed sin and death for the human race, considered or judged as sinners on the basis of Adam's sinful act. The contrast with Christ, who as the antitype of Adam thus brings grace, is explored in a discussion which probes what it means for humanity to be righteous.

In conclusion, the rabbis had a concept of sin's origin quite different from the standard Christian definition. It would be anachronistic to say of Paul's profound concept (1 Cor 15 and Rom 5) that he conceives of it in traditional categories of systematic theology. They can be used with profit to analyze his thought, and in this regard his seems most compatible with a federalist view of original sin, although appropriate caveats for the strength of conclusions on the basis of such comparison must always be present. ${ }^{61}$ For Paul the primary fact is the unrighteousness of all, but an even grander fact-and the emphasis of both 1 Corinthians 15 and Romans 5-is that Christ's work secures righteousness for mankind.

${ }^{61}$ See G. C. Berkouwer, Sin (ET Grand Rapids, Eerdmans 1971) 510 who appreciates that biblical analysis can be independent of systematictheological categories; and Berkhof, Systematic Theology 241-3 for a helpful analysis of the realist and federalist positions. 